\title{
Description of Stress and Coping Mechanism Farmer in Kalisat District Jember Regency, Indonesia
}

\section{Ananda Patuh Padaallah ${ }^{1 *}$, Emi Wuri Wuryaningsih², Alfid Tri Afandi ${ }^{3}$}

1*Faculty of Nursing, Universitas Jember, Indonesia; anandapatuh@gmail.com (Corresponding Author)

2Department of Mental Health Nursing, Nursing Facullty, Universitas Jember, Indonesia

${ }^{3}$ Department of Nursing Management, Nursing Faculty, Universitas Jember, Indonesia

\section{Article Info: \\ Submitted: \\ 29-05-2021 \\ Revised: \\ 08-06-2021 \\ Accepted: \\ 14-06-2021}

DOI:

https://doi.org/10.53713/nhs.v1i1.17

\section{(c) (i) (2)}

This work is licensed

under CC BY-SA License.

\begin{abstract}
Farmers have high risk to suffer psychological health pressure. The factors that cause farmers have psychological pressure are limited land, the decrease of soil fertility, soil degradation, and natural causes. Farmers with high psychological health pressure can suffer stress. This research aims to investigate the representation of Stress and Farmers' Coping Mechanism in Kecamatan Kalisat Kabupaten Jember. The type of this research was descriptive and simple random sampling was chosen to collect the data sampling technique. 100 farmers were collected. The respondents were measured by using farmers' stress questionnaire and Brief farmers' coping mechanism questionnaire COPE. The result of stress representation and farmer's coping mechanisme analysis showed that the number of farmer's stress tend to be cognitive response. Meanwhile, the result of coping mechanism showed that most of farmer's coping mechanism more focus on emotion rather than problem. Test the validity of the stress questionnaire obtained $r$ table $=0.497$ with $a=0.05$ and reliability of 0.703 . Whereas for the coping mechanism $a=0.05$ questionnaire, the validity of $r$ table 0.361 and the reliability of 0.778 were obtained. Ethical tests were carried out in this study at the Faculty of Dentistry, Jember University No. 465 / UN25.8 / KEPK / DL / 2019. The result of this study can be a reference for nurses and primary health care service to diagnose farmers' health diseases especially psychological diseases such as stress and coping mechanism. Nurses can do a preventive efforts, intervention, and health education about factors and symptoms of stress and coping mechanism to the farmers.
\end{abstract}

Keywords: Stress, Coping mechanism, Farmer

\section{INTRODUCTION}

Agriculture is a human activity that involves the production process to produce materials for human needs both from plants and animals, accompanied by efforts to renew, develop, and consider economic factors [1]. The economic growth of the agricultural sector in Jember was the lowest in 2016 at $3.54 \%$. According to the Jember Government, previously the economic growth rate in 2014 was still high at $6.15 \%$ and 2013 was still $6.22 \%$ [2]. Other problems experienced by farmers in farmer groups include the demands of a long job. So that it makes farmers at risk of injury, as well as other risks, namely occupational diseases such as cardiovascular disease, pesticide poisoning, and mental stress disorders [3].

Stress is a condition in individuals that is considered threatening, this threat comes from conditions from biological, psychological, and social systems [4]. Stress is also caused by an imbalance between the pressure on an individual, and the individual is unable to deal with stress so that it requires more energy to neutralize it [5].

Based on the preliminary study, it was found that $25 \%$ of the population works as farmers out of a total of 78,095 people in 2017 spread across 12 villages. In each village, there were also 64 farmer groups which could be used as information for researchers to find data. Previous research has shown that the impact of stress on farmers can be insomnia, worry about their work, irritability, stress, difficulty concentrating and tiredness. These are symptoms of stress [7]. The research objective was to describe the stress and coping mechanisms in Kalisat District, Jember Regency. 


\section{METHOD}

The research design used non-experimental quantitative research with descriptive analytic type. This study used a cross-sectional approach. The sampling technique used was total sampling, namely 100 respondents. The research data was taken from June to July 2019. The data were collected using the Farmers Stress questionnaire and the COPE BRIEF questionnaire. Data analysis was performed using univariate analysis, only describing the frequency and presentation of stress and coping mechanisms of farmers in Kalisat District, Jember Regency.

\section{RESULT}

\section{Stress}

Table 1 Mean of Stress among Farmers in Kalisat, Jember $(n=100)$

\begin{tabular}{ccc}
\hline Variable & Median & Min-Max \\
\hline Farmers stress & 40,00 & $35-46$ \\
\hline
\end{tabular}

Table 2 Stress Score according to Indicator among Farmers in Kalisat, Jember $(n=100)$

\begin{tabular}{lcc}
\hline \multicolumn{1}{c}{ Stress Indicator } & Median & Min-Max \\
\hline Cognitive Response & 16.00 & $12-18$ \\
\hline Emotional Respons & 12.00 & $8-15$ \\
\hline Behavior Respons & 14.00 & $8-16$ \\
\hline
\end{tabular}

Coping Mechanism

Table 3 Coping Mechanism Farmers in Kalisat, Jember $(n=100)$

\begin{tabular}{ccc}
\hline Variable & Median & Min-Maks \\
\hline Coping Mechanism & 77.00 & $73-95$ \\
\hline
\end{tabular}

Table 4 Coping mechanism according to Indicator among Farmers in Kalisat, Jember $(n=100)$

\begin{tabular}{ccc}
\hline Indicator & Median & Min-Max \\
\hline Problem based coping & 17.00 & $15-21$ \\
\hline Emotion based coping & 59.00 & $56-74$ \\
\hline
\end{tabular}

\section{DISCUSSION}

\section{Farmers stress}

The results showed that farmers in Kalisat District tended to be stressed on cognitive responses. Stress is an interaction between individuals and an environment that affects each other, called transactional interactions, in which there is a process of adjustment. Stress causes a person's perception to decrease and tends to focus more on minor things. The behavior carried out aims to reduce stress so that individuals need to be directed where to focus [9].

Stress has 3 indicators including cognitive response, emotional response and behavioral response. In this study, the results showed that farmers in Kalisat District tended to stress cognitive responses. These results are consistent with research conducted by Intani (2013), in which his research showed a cognitive response indicator of $72.8 \%$, an emotional response indicator of $25 \%$, and behavioral responses. amounted to $53.3 \%$ [7]. The stress assessment of the cognitive response represents a thought process disturbance and decreased concentration. Cognitive responses can be in the form of a description of the way the thinking process and the concentration of farmers, poor thought processes can affect decision making in farmers in response to work productivity [7].

\section{Coping mechanism}

The results showed that the coping mechanism among farmers in Kalisat District was more likely to use the coping mechanism to focus on the problem [11]. The coping mechanism is a mechanism that individuals use to deal with a change that occurs. Since the emergence of stressors, coping mechanisms can be studied, so that individuals can be aware of the impact of these stressors. If the individual coping mechanism is successful, then the individual can adapt to the changes that occur. The coping mechanism is divided into problem-focused coping, which aims to eliminate a 
problem, and improve the situation that presses the individual. Both coping focuses on emotions, aiming to regulate emotional responses so as not to have a negative impact on physical and psychological. [11].

The coping mechanism that focuses on the problem itself has 3 indicators including active coping, the use of help, and planning. In this study, the indicator with the highest median value was the coping mechanism to focus on emotions. This study is in accordance with previous studies on the coping mechanisms of parents with children with special needs who use emotional support more with an average of 1.36 [12]. Planning is one of the dimensions of adaptive coping, where planning is something that regulates strategies in overcoming stressful situations [13].

One of the coping mechanisms for farmers in Kalisat District, Jember Regency, is the physical health of each individual because stress requires a lot of energy, both belief and a positive outlook if farmers feel helpless about the problems they are facing, it will affect their motivation in overcoming problems, the three skills to solve problems This is trying to find other alternatives to deal with the problem, fourth, namely social skills, which means how to communicate and behave in accordance with social values in society, then social support is an emotional need from parents, siblings, friends, and the community, then materials such as needs the desired item can influence the type of coping mechanism, and finally the belief in spirituality as the basis for a person to cope with the worst situations.

\section{CONCLUSION}

In conclusion, the results and discussion of the research on the description of stress and coping mechanisms of farmers in Kalisat District, Jember Regency are as follows: the results of the study show that the stress analysis of farmers in Kalisat District tends to be an indicator of cognitive response. Kalisat farmers have a coping mechanism to focus on emotions higher than focus on problems. The results of the research can be used as an illustration of the stress and coping mechanisms of farmers so that nurses need an increase in nursing care that will be provided in the context of psychological health to farmers by means of health education about mental health and early prevention of signs and symptoms of stress and coping mechanisms by way of follow routine therapy to help farmers prevent and reduce the risk of stress.

\section{ACKNOWLEDGEMENT}

Thank you to the respondents and supervisors who have assessed the completion of this research. And thanks to all the licensing matters who have helped carry out this research well.

\section{REFERENCES}

Antaranews. (2016). Pertumbuhan ekonomi sektor pertanian di Jember terendah.

Badan Pusat Statistik Kabupaten Jember. (2018). Kabupaten Jember dalam angka: Jember Regency in figure 2018. Jember: Badan Pusat Statistik.

Carver CS. Scheier MF \& Weintraub JK. (1989). Assesing coping strategies: a theoretically based approach. Journal of Personality and Social Psychology, 56, 267-283.

Dhini, D. R. (2010). Pengaruh stres kerja, beban kerja terhadap kepuasan kerja (studi pada medical representatif di kota kudus).

Hidayati A. (2017). Hubungan health locus of control dengan mekanisme pada pasien diabetes melitus Tipe 2 di wilayah kerja puskesmas patrang kabupaten jember. Jember: Program Studi IImu Keperawatan Universitas Jember.

Intani, A.C. (2013). Hubungan beban kerja dengan stres pada petani lansia di kelompok tani tembakau kecamatan sukowono kabupaten jember. Skripsi. Jember: Program Studi IImu Keperawatan Universitas Jember

Lazarus, R.S. \& Folkman, S. (1984). Stres Apprasial and Coping. Newyork: Springer Publishing Company, Inc.

Nursalam. (2015). Metodologi penelitian ilmu keperawatan: Pendekatan Praktis Edisi 3. Jakarta: Salemba Medika

Rifai, A., A.T. Afandi, \& E. Rindiantika. (2019). The Correlation Between Transcultural Nursing Competencies and Hospital-based Nursing Therapeutic Communication in Jember, Indonesia. The 2nd Andalas International Nursing Conference 2019. Sciendo.

Sari, CWK. (2018). Kejadian dan karakteristik cidera pada petani di kecamatan kalisat kabupaten jember. Skripsi. Jember: Program Studi IImu Keperawatan Universitas Jember.

Stuart GW. (2016). Principles of psychiatric nursing. 10th edition. Mosbu: Elsevier. Translated by Budi, A. K \& Jesika, P. Prinsip dan praktik keperawatan kesehatan jiwa stuart. Edisi pertama. Indonesia: Elsevier.

Sudut Kalisat. (2016). Kalisat di mata pak camat.

Susanto, T, Purwandari, R \& Wuryaningsih, E.W. (2016). Model perawatan kesehatan keselamatan kerja berbasis agricultural nursing: studi analisis masalah Kesehatan Petani. Jurnal Ners, 11(1), 45-50.

Suwandari, A. R. (2006). Pengantar ilmu pertanian. Malang: Bayumedia. 